\title{
THE PERCEPTION OF MEDICAL STUDENTS IN CLINICAL YEARS TOWARDS BEDSIDE TEACHING IN UNIVERSITI MALAYSIA SARAWAK (UNIMAS)
}

\author{
Nur Amir Luqman Roslan \\ Faculty of Medicine and Health Sciences, University Malaysia Sarawak, Kota Samarahan, \\ Malaysia \\ Betty Tang Jin Jin \\ Faculty of Medicine and Health Sciences, University Malaysia Sarawak, Kota Samarahan, \\ Malaysia \\ Noor Syafawani Bohan \\ Faculty of Medicine and Health Sciences, University Malaysia Sarawak, Kota Samarahan, \\ Malaysia

\section{Hashveena Veerakumar} \\ Faculty of Medicine and Health Sciences, University Malaysia Sarawak, Kota Samarahan, \\ Malaysia

\section{Siti Maryam Ahmad Kendong} \\ Faculty of Medicine and Health Sciences, University Malaysia Sarawak, Kota Samarahan, \\ Malaysia

\section{Saiful Bahri Talip*} \\ Faculty of Medicine and Health Sciences, University Malaysia Sarawak, Kota Samarahan, \\ Malaysia
}

Corresponding author

Email: tsbahri@unimas.my

\begin{abstract}
This study was done to survey on the different perceptions among medical students toward bedside teaching that includes both the pros and cons of this type of learning method. A 130 clinical year students (Year 3, Year 4, Year 5) from Faculty of Medicine and Health Science (FHMS) of Universiti Malaysia Sarawak (UNIMAS) participated in this study. Questionnaires consisted of three different sections were distributed and the collected data were analyzed using Analysis of Variance (ANOVA) test. From the study, it was found that, clinical year students had perceived differently regarding the bedside teaching mainly on three aspects. These includes the care given by students to their patients, the increased risk of exposure to diseases, and more than 1 lecturer per group during teaching $(P<0.05)$. Majority of the students agreed that bedside teaching is the most straight forward method to convey knowledge, promoting better understanding, encouraging active learning, developing better clinical skills and nurturing crucial ethical aspects. Students also agreed that bedside teaching in UNIMAS can be improved by respecting confidentiality of patients, summarising each discussion session, encouraging feedback and using simple terms during teaching session.. As conclusion, from this study, it was found that there were a few different in the perceptions toward bedside teaching between clinical year students of UNIMAS.
\end{abstract}

Keywords: Bedside teaching, Medicine, Learning method, Knowledge 


\section{INTRODUCTION}

Bedside teaching (BST) is one of the important learning methods in medical education and it involves teaching the students with the presence of their patients. During BST sessions, medical students will consider their patients as true patients, not just a 'sample' of a disease and they also need to observe the physical condition of their patients directly that will assist them indirectly to understand the diseases (Aldeen \& Gisondi, 1996). Bedside teaching is an effective technique to enhance the student's skills especially on the history taking technique, physical examination, communication and professionalism (Branch et al., 2001). Some research had found that BST is the most favourable teaching method as compared to other teaching methods for medical students (Billings et al., 2010).

BST plays a major role in engaging the medical students with independent thought. Independent thought happens when the students learn to make their conclusions on the diagnoses and treatments based on their own interpretations on the clinical data. Although there were 21 public and private medical schools present in Malaysia but there was no study on BST done at medical school in Borneo (Lim, 2008). Nevertheless, before the students start to diagnose the disease of their patient, the lecturers should inform their students that the information which they had gathered should come together with the differential diagnosis and not only involve the history taking and physical examination (Wolpaw TM, Wolpaw DR \& Papp, 2003). BST is found to be very crucial to help the medical students to enhance their understanding on a doctor-patient relationship, especially on patient-centeredness (Qureshi \& Maxwell, 2012). However, there is a negative perception which may limit the practice of BST in which this method could make the patients stressful (Simons, Bailey \& Zwilich, 1989).

Ramani and Leinster (2008) defined BST as teaching within a clinical setting in which learning is highly focus on real patients. The patients can be hospital inpatients or outpatients (OPD), from emergency departments (ED) and from community settings. Bedside teaching method was originated from Italy since $18^{\text {th }}$ century and it was first introduced into medical school's curriculum during that period of time (Jolly, Harris \& Peyton, 1998). However, during that time, the medical education was still relying on books and lectures and therefore, BST was not very well-known (Doman \& Flexner, 2005). Nevertheless, the popularity of BST seemed to peak during 1960s and became one of the major learning methods in medical schools (Crumlish, Yialamas \& McMahon, 2009).

It was found that more than half of the case studies clerked by the medical students during BST can be diagnosed after the history taking and up to $75 \%$ can be diagnosed by the end of the physical examinations (Ahmed, 2010). Bedside teaching also has been implemented at UNIMAS medical faculty. This learning method is conducted during the clinical years and the teaching process takes place at Sarawak General Hospital, Serian Hospital and Sibu Hospital. BST is conducted by dividing the students into several smaller group and they will be accompanied by their lecturer with the presence of a real patient (Gill, 2003). This learning process is conducted based on the provided schedule. The students have to clerk a case and they need to present their case in front of their respective lecturers as well as their colleagues (Longlois \& Thach, 2000). Then the students will discuss about their patient's problem with their lecturers and obtain a feedback from them.

However, one of the obstacles of bedside teaching that the students have to face is time constraint due to the shortened admission time of the patients and pressure of the physician to clerk more patients with increased number of record keeping (Salam et al., 2011). The lack of 
knowledge of medical students on basic science and clinical skills also lead to the challenging setting in learning through bedside teaching. Some of the students are also not very fluent with local language and this is also one of the barriers for them to conduct bedside teaching (Holla et al., 2015). According to Janicik and Fletcher (2003), the ideal bedside teaching should consist of 3 main domains which include tackling patient's comfort, focused teaching and group effectiveness. Weissmann et al. (2006) had stated that positive role model was considered to be one of the exclusive ways to teach medical students to enhance their desirable manners and behaviours.

\section{METHOD}

\section{Participants}

Participants for this study are 113 undergraduate medical students from year three until year five (38 year three students, 37 year four students, 38 year five students) of Faculty of Medicine and Health Science (FMHS) from University Malaysia Sarawak (UNIMAS). The inclusion criteria was clinical year students at FMHS, UNIMAS and exclusion criteria was pre-clinical medical students which include year 1 and year 2 students from FMHS, UNIMAS and also the student who take the other courses at UNIMAS. The clinical students were chosen for this study due their experience with BST in their curriculum.

\section{Materials}

The information on clinical students' perceptions towards BST was collected using a questionnaire which had been validated through a pilot study involving the pre-clinical students. The questionnaire was approved by FMHS Ethics Committee.

The questionnaire was divided into three main sections: Section A, Section B and Section C. As for Section A, the students were required to fill in their basic information on their year of study, gender and race. Meanwhile for section B, the students were asked to rate for the most preferable learning method in clinical years and were assessed using Likert's scale. It involves five selection of rating ranging from strongly agree to strongly disagree. Lastly for Section C, the students were given open ended questions regarding the most preferable as well as the most dislike teaching method.

\section{Procedure}

This study was a cross-sectional study and it was conducted from $30^{\text {th }}$ July 2015 to $30^{\text {th }}$ June 2016. Purposive sampling method was implemented to select the research participants.

The meeting with the clinical students took place at UNIMAS city campus, Kuching branch. During this meeting, the consent forms were distributed to students prior to data collection. The questionnaires were given to the clinical students along with the consent forms. Both consent forms and questionnaire were returned back after one month. The total number of questionnaire was double-checked to prevent incorrect number of sample size for analysis.

The quantitative data from the questionnaire were analyzed using SPSS software version 23.0. The sampling data were described and interpreted in the forms of frequency, mean, standard deviation (for normal distributed data), median and interquartile range (for nonnormal distributed data). One way ANOVA test was also conducted to determine if there was a significant difference in the means between the study parameters. The significant $p$ - value 
was set at 0.05 . The data parameter was considered to be significant if the p-value was less than 0.05 and the null hypothesis for this study will be rejected.

\section{RESULT}

Based on Table 1, Item no.1 showed significant difference in the students' perception with a $p$-value of less than $0.05(p=0.001)$. For item no.1, majority of the students neither agree nor disagree whether the patients appreciate the care given by the student to them. The mean score for item no. 1 is $2.42(\mathrm{SD}=0.826)$ for Year 3, $3.16(\mathrm{SD}=0.834)$ for Year 4 and $2.82(\mathrm{SD}=0.865)$ for Year 5. However, item no.2 proved to be not significant in the difference in students' perception, with $p$-value more than $0.05(p=0.945)$. The mean score for item no.2 is 2.74 $(\mathrm{SD}=1.005)$ for year $3,2.68(\mathrm{SD}=0.784)$ for year 4 and $2.74(\mathrm{SD}=0.921)$ for year 5.

Table 1: The perception of the students regarding patient involvement during bedside teaching (BST)

\begin{tabular}{|l|c|c|c|c|c|}
\hline \multicolumn{1}{|c|}{ Items } & $\begin{array}{c}\text { Year of } \\
\text { Study }\end{array}$ & Mean & $\begin{array}{c}\text { Std. } \\
\text { Deviation } \\
\text { (SD) }\end{array}$ & $\begin{array}{c}\text { Std. } \\
\text { Error } \\
\text { Mean } \\
\text { (SEM) }\end{array}$ & $p$-value \\
\hline $\begin{array}{l}\text { 1. Patients appreciate } \\
\begin{array}{l}\text { the care given to } \\
\text { them by the student }\end{array}\end{array}$ & Year 3 & 2.42 & 0.826 & 0.134 & 0.001 \\
& Year 4 & 3.16 & 0.834 & 0.137 & \\
\hline $\begin{array}{l}\text { 2. Patients become } \\
\text { burdened and stressed }\end{array}$ & Year 3 & 2.82 & 0.865 & 0.140 & \\
& Year 4 & 2.68 & 0.784 & 0.129 & 0.945 \\
& Year 5 & 2.74 & 0.921 & 0.149 & \\
\hline
\end{tabular}

Based on Table 2, item no.3 showed significant difference in the students' perception with $p$-value less than $0.05(p=0.031)$. For item no.3, it was found that there were equal number of students who were neutral and agreed that BST had increased risk of exposure to infectious disease. Mean score for item no.3 is $2.47(\mathrm{SD}=0.979)$ for Year 3, $2.46(\mathrm{SD}=0.900)$ for Year 4 and $2.97(\mathrm{SD}=0.972)$ for Year 5. However for item 4, there were no significant difference in the students' perception, with $p$-value more than $0.05(p=0.084)$. The mean score for item no.4 is $2.95(\mathrm{SD}=0.928)$ for year 3, $3.32(\mathrm{SD}=1.056)$ for year 4 and $3.42(\mathrm{SD}=0.919)$ for year 5 .

Table 2: The students' perception on learning environment of bedside teaching

\begin{tabular}{|c|c|c|c|c|c|}
\hline Items & $\begin{array}{c}\text { Year of } \\
\text { study }\end{array}$ & Mean & $\begin{array}{c}\text { Std. } \\
\text { Deviation } \\
\text { (SD }\end{array}$ & $\begin{array}{c}\text { Std. } \\
\text { Error } \\
\text { Mean } \\
\text { (SEM) }\end{array}$ & $p$-value \\
& & & & \\
\hline
\end{tabular}




\begin{tabular}{|c|c|c|c|c|c|}
\hline $\begin{array}{l}\text { 3. } \text { Increased risk } \\
\text { exposed to infectious } \\
\text { diseases }\end{array}$ & $\begin{array}{l}\text { Year } 3 \\
\text { Year } 4 \\
\text { Year } 5\end{array}$ & $\begin{array}{r}2.47 \\
2.46 \\
2.97 \\
\end{array}$ & $\begin{array}{l}0.979 \\
0.900 \\
0.972\end{array}$ & $\begin{array}{l}0.159 \\
0.148 \\
0.158 \\
\end{array}$ & 0.031 \\
\hline $\begin{array}{l}\text { 4. The learning } \\
\text { atmosphere is } \\
\text { unappealing for } \\
\text { students }\end{array}$ & $\begin{array}{l}\text { Year } 3 \\
\text { Year } 4 \\
\text { Year } 5\end{array}$ & $\begin{array}{l}2.95 \\
3.32 \\
3.42\end{array}$ & $\begin{array}{l}0.928 \\
1.056 \\
0.919\end{array}$ & $\begin{array}{l}0.151 \\
0.174 \\
0.149\end{array}$ & 0.084 \\
\hline
\end{tabular}

Based on Table 3, item no.5 showed significant difference in the students' perception with a $p$-value less than $0.05(p=0.047)$. Most of the students disagreed that more than 1 lecturer per group is a good recommendation. Mean score for item no.5 is $3.08(\mathrm{SD}=0.997)$ for Year 3, $3.38(\mathrm{SD}=1.063)$ for Year 4 and $3.68(\mathrm{SD}=3.68)$ for Year 5. However for item no.6 there were no significant difference in the perception with $p$-value more than $0.05(p=0.061)$. The mean score for item no.6 is $2.61(\mathrm{SD}=1.054)$ for year $3,2.19(\mathrm{SD}=0.908)$ for year 4 and 2.11 $(\mathrm{SD}=0.953)$ for year 5 .

Table 3: The perception of the students on the recommendations to improve bedside teaching

\begin{tabular}{|l|l|c|c|c|c|}
\hline Items & $\begin{array}{c}\text { Year of } \\
\text { Study }\end{array}$ & Mean & $\begin{array}{c}\text { Std. } \\
\text { Deviation } \\
\text { (SD) }\end{array}$ & $\begin{array}{c}\text { Std. } \\
\text { Error } \\
\text { Mean } \\
\text { (SEM) }\end{array}$ & p-value \\
\hline $\begin{array}{l}\text { 5. More than 1 lecturer } \\
\text { per group }\end{array}$ & Year 3 & 3.08 & 0.997 & 0.162 & \\
& Year 4 & 3.38 & 1.063 & 0.175 & 0.047 \\
\hline $\begin{array}{l}\text { 6ess student per } \\
\text { group (3-4 students) }\end{array}$ & Year 5 & 3.68 & 3.68 & 0.177 & \\
& Year 3 & 2.61 & 1.054 & 0.171 & \\
& Year 4 & 2.19 & 0.908 & 0.149 & 0.061 \\
\hline
\end{tabular}

\section{DISCUSSION}

The students' perception was divided based on its nature; lecturers' teaching style, patients and environments. There were only three significant finding from this study. One of these significant finding was that the students disagreed that the patients appreciate the care given by the students to them. However, this finding was contradicted with study did by Sayyed-Hassan, Bashour and Koudsi (2012) in which they had found that the patients expressed their 
satisfaction when they were given attention and their cases were discussed thoroughly by the students. Furthermore, this study also found that there was significant different in students' perception toward the risk of exposure to infectious diseases. This finding was corresponded with a study done by Gill (2003) in which they had found that there was increase in the risk of nosocomial infection with high numbers of students present in the group.

The third significant finding for this study was regarding on the recommendation to have more than 1 lecturer per group. Other studies have shown that the errors of diagnosis and management were less likely to happen with the present of extra comments and critical opinions from the numerous lecturers. This also leads to deeper understanding on the condition of the patients (Ahmed, 2010).

\section{CONCLUSION}

In general, it can be concluded that year three, year four and year five students had the same perception on bedside teaching and the recommendations for bedside teaching. All of the three groups of students agreed that bedside teaching is a good teaching method in which it improve the students' clinical skills and promote higher-level of intellectual skills. This study also found that there were only a few differences in students' perceptions towards bedside teaching.

\section{Acknowledgement}

We would like to thank the Faculty of Medicine and Health Sciences for giving us the opportunity to do this research including Dr-Khatijah, A/P Dr. Nor Aliza Abdul Rahim, Dr. Saiful Bahri Bin Talip and Madam Siti Maryam Binti Ahmad Kendong for guidance. We also like to thank the clinical students who participated in this study. Lastly, we would like to thank our parents, lecturers and friends who have given us moral support throughout the duration of this project.

\section{REFERENCES}

Aldeen, A.Z. and Gisondi MA. (2006). Bedside teaching in the emergency department. Acad Emerg Med, 13(8), pp. 860-866.

Branch WT Jr., Kern D, Haidet P, Weissmann P, Gracey CF, Mitchell G, et al. The patient-physician relationship. Teaching the human dimensions of care in clinical settings. JAMA 2001; 286: 10671074.

Billings ME, Engelberg R, Curtis JR, Block S, Sullivan AM. Determinants of medical students' perceived preparation to perform end-of-life care, quality of end-of-life care education, and attitudes toward end-of-life care. J Palliat Med 2010; 13:319-326.

Lim, V.K.E. (2008). Medical education in Malaysia. Informa UK Ltd. ; 30: 119-123.

Wolpaw TM, Wolpaw DR, Papp KK. SNAPPS: A learner-centered model for outpatient education. Acad Med. 2003;78:893-898.

Qureshi Z, Maxwell S. Has bedside teaching had its day?Adv Health Sci Educ2012;17:301-4. 
Simons RJ, Bailey RG, Zwillich CW. 1989. The physiological and psychological effects of the bedside presentation. N Eng J Med 321:1273-1275.

Ramani, S. and Leinster, S. (2008). AMEE Guide no. 34: Teaching in the clinical environment. Med Teach, 30, 347-364.

Jolly, B., Harris, D. and Peyton, R. (1998). Teaching with patients. In: Peyton JWR, editor. Teaching and Learning in medical practice. London: Manticore Europe limited, p. 157.

Dornan T. Osler, Flexner, Apprenticeship and 'the new medical education'. J R Soc Med 2005; 98:915.

Crumlish, C.M., Yialamas, M.A. and McMahon, G.T. (2009). Quantification of bedside teaching by an academic hospitalist group. J Hosp Med, 4, 304-7.

Ahmed, A. M. (2010). Bedside teaching at the Cinderella status. Saudi Med J, 31(7), pp. 739-746.

Gill, D. (2003). Teaching and learning 'at the bedside', Available from http://www.faculty.londondeanery.ac.uk/e_learning/explorefurther/teaching_and_learning_at_th e_bedside.pdf Howley, L. D. \& Wilson, W. G. (2004) Direct Observation of Students during Clerkship Rotations: A Multiyear Descriptive Study. Academic Medicine, 79(3), 276-280.

Langlois, J.P. and Thach, S. (2000). Teaching at the bedside. Fam Med. 32, 528-30.

Salam, A., Siraj, H. H., Mohamad, N., Das, S. and Yousuf, R.(2011). Bedside teaching in undergraduate medical education: issues, strategies, and new models for better preparation of new generation doctors. Iranian journal of medical sciences, 36(1), pp. 1-6, viewed 17 December2015,http://www.pubmedcentral.nih.gov/articlerender.fcgi?artid=3559110\&tool=pmce ntrez\&rendertype $=$ abstract

Holla, R., Shrisha, M., Unnikrishnan, B., Sharma, N., Janani, S., Thapar, R., Mithra, P., Kumar, N., Kulkarni, V., Darshan BB, Kumar, A., Reddy, K. \& Prakash, D. (2015). Facilitators and barriers for bedside teaching in the teaching hospitals of coastal south india. Asian Journal of Pharmaceutical and Clinical Research, 8 (2), pp. 271-273.

Janicik, R. W. and Fletcher, K. E. (2003). Teaching at the bedside: a new model. Medical Teacher, 25 (2), pp. 127-130.

Weissmann, P.F., Branch, W.T., Gracey, C.F., Haidet, P. and Frankel, R.M. (2006). Role modeling humanistic behavior: learning bedside manner from the experts. Acad Med ,81,661-7.

Sayed-Hassan, R.M., Bashour, H.N. \& Koudsi, A.Y. (2012). Patient attitudes towards medical students at Damascus University teaching hospitals. BMC Medical Education, (12)13, pp. 1-8. 